DOI: $10.1590 / 0100-83582015000200002$

Assessing the competitive ability of Rhynchosia capitata; an ...

\title{
Assessing the Competitive AbILIty of Rhynchosia capitata; AN Emerging Summer Weed In Asia ${ }^{1}$
}

\author{
Avaliação da Capacidade Competitiva de Rhynchosia capitata; uma Erva Daninha de Verão \\ Emergente na Ásia
}

\author{
ALI, H.H.2, TANVEER, A. ${ }^{3}$, NAEEM, M.2, JAMIL, M.2, IQBAL, M. ${ }^{2}$, CHADHAR, A.R. ${ }^{4}$, and \\ KASHIF, M.S. ${ }^{5}$
}

\begin{abstract}
Rhynchosia capitata is a newly emerging threatening weed of summer crops in many Asian countries. We conducted 2-yr experiments to evaluate $R$. capitata competition with mungbean under irrigated conditions. Rhynchosia capitata was allowed to compete with mungbean for $0,3,4,5,6,7$ weeks after planting and for full crop season. The competitive ability of $R$. capitata was assessed by measuring its dry weight, micro and macro nutrient contents and uptake; and its effects on mungbean growth and yield parameters. The results showed that full season weed competition produced highest dry weight of $R$. capitata and its macro and micronutrient contents and uptake. Yield and yield components of mungbean decreased in a linear fashion with increase in competition period of Rhynchosia capitata. Full season competition of $R$. capitata reduced the seed yield of mungbean by $49 \%$ and $46 \%$ during 2011 and 2012 respectively. In conclusion, damaging effect of $R$. capitata intrusion on mungbean yield is associated with duration of its presence in crop, accumulation of dry matter and the nutrient uptake by R. capitata, which otherwise should be available to crop.
\end{abstract}

Keywords: Rhynchosia capitata, emerging, infestation, competition, mungbean, nutrients.

\begin{abstract}
RESUMO - Rhynchosia capitata é uma erva daninha recém-emergente e ameaçadora das culturas de verão em muitos paises asiáticos. Foram realizados experimentos de dois anos para avaliar a concorrência de $\boldsymbol{R}$. capitata com feijão-da-china ou feijão-mungo sob condições irrigadas. Rhynchosia capitata ficou em competição com feijão-da-china ou feijão-mungo por 0, 3, 4, 5, 6, 7 semanas após o plantio e na temporada completa de colheita. A habilidade competitiva de $\boldsymbol{R}$. capitata foi avaliada medindo-se seu peso seco, conteúdo e absorção de micro e macro nutrientes e seus efeitos sobre o crescimento e caracteristicas de rendimento de feijão-da-china ou feijão-mungo. Os resultados mostraram que a competição com ervas daninhas na temporada completa produziu o mais alto peso seco e seu conteúdo e absorção de micro e macro nutrientes $\boldsymbol{R}$. capitata. O rendimento e os componentes de rendimento de feijão-da-china ou feijão-mungo diminuiram de modo linear com o aumento do periodo de concorrência de Rhynchosia capitata. A concorrência na temporada completa de $\boldsymbol{R}$. capitata reduziu a produção de sementes de feijão-da-china ou feijão-mungo em 49\% e 46\% durante 2011 e 2012 respectivamente. Em conclusão, os efeitos prejudiciais da intrusão de $\boldsymbol{R}$. capitata no rendimento de feijão-da-china ou feijão-mungo são associados com a duração de sua presença na colheita, acúmulo de matéria seca e a ingestão de nutrientes por $\boldsymbol{R}$. capitata, que, de outro modo, deveria estar disponivel para a colheita.
\end{abstract}

Palavras-chave: Rhynchosia capitata, emergência, infestação, competição, feijão-da-china ou feijão-mungo, nutrientes.

\footnotetext{
${ }^{1}$ Recebido para publicação em 15.8.2014 e aprovado em 6.10.2014.

2 University College of Agriculture and Environmental Sciences, The Islamia University of Bahawalpur, Pakistan, <haider3993@gmail.com>; ${ }^{3}$ University of Agriculture, Faisalabad, Pakistan; ${ }^{4}$ Deputy District Officer, On Farm Water Management Wing, Punjab Agriculture Department, Pakistan; ${ }^{5}$ Farm Manager, Extension and Adaptive Research Wing, Punjab Agriculture Department, Pakistan.
}

Planta Daninha, Viçosa-MG, v. 33, n. 2, p. 175-182, 2015 


\section{INTRODUCTION}

The genus Rhynchosia of Fabaceae family is widely distributed in the mountainous regions of the tropics. Rhynchosia capitata (Roth) DC is an emerging annual summer weed in Pakistan (Ali et al., 2013). It is indigenous to India (Dogra et al., 2009), Pakistan and Sri Lanka (ILDIS, 2010). It has invaded the agro-ecosystems of Southern Punjab, Pakistan and is increasingly becoming a problematic weed in farming systems (Ali et al., 2013a). In the field, the weeds emerge through seeds just after irrigation. It is an annual twinning prostrate plant with many branches spreading all around the rootstock and rooting at every node. An approximately 1-mo-old plant starts flowering and the plant has oval-shaped pods with two seeds in each pod (Sharma et al., 1978). The growing season is from May to October with minimum and maximum average temperatures of $29 /$

$21 \pm 3 \circ \mathrm{C}$ and $39 / 29 \pm 3 \circ \mathrm{C}$, respectively, and average rainfall of $650 \mathrm{~mm}$ (Ali et al., 2012). Seeds usually require scarification to germinate. Seed dormancy is an important reason towards the success of this species, due to which seeds of this species persist for long periods in the soil and thus escape the effects of post-emergence weed control measures (Ali et al., 2011). In addition to its competitive effects on major crops, it adversely affects harvest efficiency and crop quality.

Mungbean [Vigna radiata (L.) Wilczek] is one of the major pulse crops supplementing the cereal-based diet of poor population in Asia. It is cultivated on irrigated as well as on dry areas of Pakistan. Average yield of mungbean in Pakistan is $800-1,000 \mathrm{~kg} \mathrm{ha}^{-1}$ against the potential yield of $2,000 \mathrm{~kg} \mathrm{ha}^{-1}$ for available cultivars (Arshad et al., 2006). The main factors that contribute towards low yield of mungbean include high cost of inputs, conventional sowing methods, sowing on marginal land, low or no use of fertilizers and poor weed management practices. Uncontrolled weeds can cause reduction in mungbean seed yield ranging from 27 to 100\% (Malik et al., 2000; Pandey \& Mishra, 2003; Raman \&
Krishnamoorthy, 2005) depending upon type of weeds, density of weeds, duration of weed infestation, time and method of crop sowing, fertilizer application method and other environmental factors (Mansoor et al., 2004).

Weed-crop competition is an important aspect of all biological factors that can considerably reduce the crop yield (Deen et al., 2003). This happens mainly due to higher resource utilization potential of weeds than that of crop (McDonald et al., 2004). Numerous studies have assessed the crop weed competition period in a variety of crops and measured its significance and the timing of optimum weed control (Norsworthy $\&$

Oliveira, 2004). For attaining an effective weed control, knowledge of critical period of weedcrop competition is necessary, as it plays a decisive role in weed management (Deen et al., 2003). Mungbean is considered to be a sensitive crop to weed competition (Moody, 1978). Keeping in view the importance of $R$. capitata management in mungbean, the present study was planned to assess the competitive ability of $R$. capitata and the yield losses in mungbean caused by Rhynchosia capitata under irrigated conditions.

\section{MATERIAL AND METHODS}

The study was carried out in mungbean fields for two consecutive years (2011 and 2012) having a heavy invasion of $R$. capitata since 2005. The experiment was laid out in a randomized complete block design with 4 replications. The treatments comprised zero competition (control), weed crop competition for $3,4,5,6$ and 7 weeks after planting and full season competition. The soil was sandy loam with $\mathrm{pH}$ of 8.0 and 8.3 and EC of 1.11 and $1.04 \mathrm{dS} / \mathrm{m}$ during the first and second years of study, respectively. Organic matter, total $\mathrm{N}$, available $\mathrm{P}$ and $\mathrm{K}$ were $0.55 \%$, $0.029 \%, 5.54 \mathrm{mg} \mathrm{kg}^{-1}, 240 \mathrm{mg} \mathrm{kg}^{-1}$ during the first year (2011) and $0.71 \%, 0.039 \%, 8.03 \mathrm{mg}$ $\mathrm{kg}^{-1}$ and $173 \mathrm{mg} \mathrm{kg}^{-1}$ during the second year (2012) of study. During the growing season of mungbean, meteorological data regarding temperature and rainfall (means on a monthly basis) were obtained from the 
Agronomic Research Station, Karor, district Layyah, Punjab, Pakistan (Figure 1).

A pre-soaking irrigation was applied before the seed bed preparation. When the soil reached the proper moisture level (field

C) 140

an

d 120

$\mathrm{Ra}$

inf 100

all

(m 80

$\mathrm{m})$

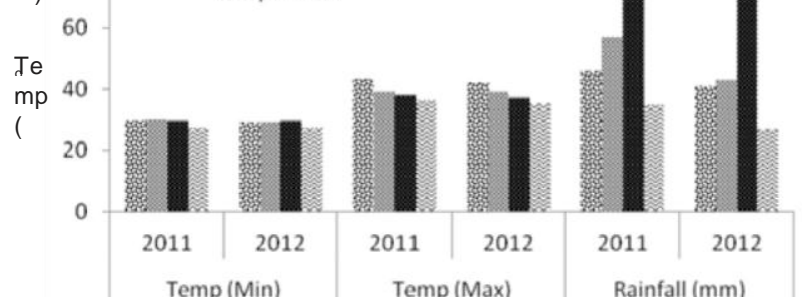

Figure 1 - Climatic data for the growth season of mungbean for 2011 and 2012.

capacity), the seed bed was prepared by cultivating the soil 2-3 times with the tractor mounted cultivator, each time followed by planking. Mungbean (cv. AZRI-2000) was planted at a seed rate of $25 \mathrm{~kg} \mathrm{ha}^{-1}$ with single row hand drill in $30 \mathrm{~cm}$ apart rows. Plant to plant distance of $15 \mathrm{~cm}$ was maintained by thinning out the extra plants 10 days after emergence. Net plot size was $1.2 \mathrm{~m} \times 6 \mathrm{~m}$. Three irrigations were applied at three weeks after sowing, at the flower initiation stage and at seed filling stage to avoid drought stress to crop. Nitrogen and phosphorus were applied at 25 and $50 \mathrm{~kg}$ ha1 in the form of urea and diammonium phosphate (DAP), respectively at the time of sowing of mungbean. Weeds were removed manually with a hand hoe from the respective plots after the prescribed duration and then kept weed free till harvest.
All the other agronomic practices were kept uniform for all the treatments from sowing till harvesting. In each year, mungbean was manually harvested by sickle in the $2^{\text {nd }}$ week of September at ground level, bundled, airdried, and weighed.

Standard procedures were adopted for recording the data on various growth and yield parameters of $R$. capitata and mungbean. Ovendried plant samples of Rhynchosia capitata were ground with a grinder and NPK contents (\%) were determined as suggested by AOAC (1984) and micronutrient contents were determined as suggested by Jan et al. (2011). Individual year data were subjected to statistical analysis by using Fisher's Analysis of Variance techniques (Steel et al., 1997). The polynomial trends across the treatments were compared. Three components of trend in increasing complexity, i.e. linear, quadratic, and cubic were analyzed. Least significant difference (LSD) test was applied at 5\% probability level to test the significance of treatment means.

\section{RESULTS AND DISCUSSION}

Dry weight of $R$. capitata was considerably affected by varying $R$. capitata competition periods. It showed an increasing tendency as the $R$. capitata competition period was extended (Figure 2). Maximum dry weight (58.25 g, $67.25 \mathrm{gm}^{-2}$ in 2011 and 2012, respectively) of $R$. capitata was observed in plots where $R$. capitata plants were allowed to compete with the mungbean crop for full season. These results are in line with those of Naeem et al. (2000) who also reported a linear increase in weed dry weight with increase in the weed-crop competition period of mungbean.

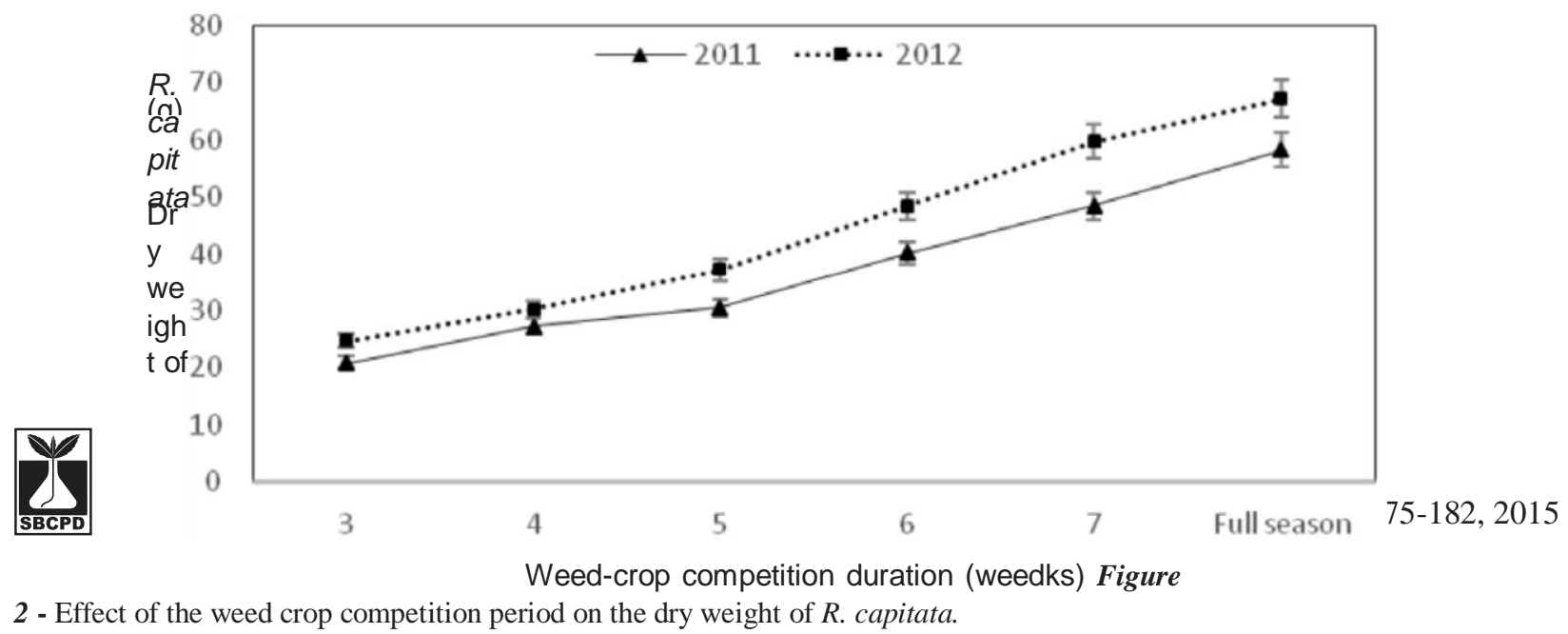


Significant differences in NPK contents and uptake by $R$. capitata were observed during both years (Table 1). There was a linear increase in the NPK contents (\%) and uptake (kg ha-1) by $R$. capitata with increase in the $R$. capitata competition period. Minimum NPK contents and uptake by $R$. capitata were recorded in the competition period of 3 weeks during both years of the study. During both years of the study, $R$. capitata NPK contents showed an increasing linear response whereas NPK uptake showed a linear as well as a quadratic response to its increasing competition period (Table 1). In competition periods of 3 and 4 weeks, $R$. capitata plants were not fully grown, hence resulting into lesser competition as compared to competition periods of 5,6 and 7 weeks. Hence, $R$. capitata plants had less NPK contents in the short duration competition period (3-4 weeks) as compared to the longer competition period (5-7 week competition).

The linear increase in the NPK contents with the enhancement of $R$. capitata competition periods may possibly be due to more use of light, water and nutrients by $R$. capitata. More biomass observed in the weedy check could be the outcome of a higher $\mathrm{N}$ uptake by $R$. capitata as weed plants remained in the field throughout the

Table 1 - Macronutrient contents and uptake by $R$. capitata at different competition durations with mungbean

\begin{tabular}{|c|c|c|c|c|c|c|c|c|c|c|c|c|}
\hline \multirow{3}{*}{$\begin{array}{l}\text { Duration of } \\
\text { weed-crop } \\
\text { competition } \\
\text { (WAP)** }\end{array}$} & \multicolumn{4}{|c|}{$\mathrm{N}$} & \multicolumn{4}{|c|}{$\mathrm{P}$} & \multicolumn{4}{|c|}{ K } \\
\hline & \multicolumn{2}{|c|}{ Content $(\%)$} & \multicolumn{2}{|c|}{ Uptake $\left(\mathrm{kg} \mathrm{ha}^{-1}\right)$} & \multicolumn{2}{|c|}{ Content $(\%)$} & \multicolumn{2}{|c|}{ Uptake $\left(\mathrm{kg} \mathrm{ha}^{-1}\right)$} & \multicolumn{2}{|c|}{ Content $(\%)$} & \multicolumn{2}{|c|}{ Uptake $\left(\mathrm{kg} \mathrm{ha}^{-1}\right)$} \\
\hline & 2011 & 2012 & 2011 & 2012 & 2011 & 2012 & 2011 & 2012 & 2011 & 2012 & 2011 & 2012 \\
\hline 3 & $1.37 * \mathrm{f}$ & $1.49 \mathrm{f}$ & $3.12 \mathrm{e}$ & $3.70 \mathrm{e}$ & $1.39 \mathrm{~d}$ & $1.40 \mathrm{e}$ & $2.92 \mathrm{e}$ & $3.50 \mathrm{e}$ & $2.16 \mathrm{e}$ & $2.23 \mathrm{f}$ & $4.54 \mathrm{e}$ & $5.52 \mathrm{f}$ \\
\hline 4 & $1.72 \mathrm{e}$ & $1.82 \mathrm{e}$ & $4.95 \mathrm{de}$ & $5.49 \mathrm{e}$ & $1.49 \mathrm{~d}$ & $1.51 \mathrm{e}$ & $4.06 \mathrm{~d}$ & $4.57 \mathrm{e}$ & $2.27 \mathrm{e}$ & $2.36 \mathrm{e}$ & $6.19 \mathrm{de}$ & $7.15 \mathrm{e}$ \\
\hline 5 & $2.13 \mathrm{~d}$ & $2.27 \mathrm{~d}$ & $6.95 \mathrm{~d}$ & $8.43 \mathrm{~d}$ & $1.65 \mathrm{c}$ & $1.75 \mathrm{~d}$ & $5.07 \mathrm{~d}$ & $6.54 \mathrm{~d}$ & $2.49 \mathrm{~d}$ & $2.53 \mathrm{~d}$ & $7.57 \mathrm{~d}$ & $9.46 \mathrm{~d}$ \\
\hline 6 & $2.56 \mathrm{c}$ & $2.71 \mathrm{c}$ & $10.92 \mathrm{c}$ & $13.18 \mathrm{c}$ & $1.80 \mathrm{~b}$ & $1.94 \mathrm{c}$ & $7.27 \mathrm{c}$ & $9.44 \mathrm{c}$ & $2.66 \mathrm{c}$ & $2.72 \mathrm{c}$ & $10.72 \mathrm{c}$ & $13.20 \mathrm{c}$ \\
\hline 7 & $3.03 \mathrm{~b}$ & $3.16 \mathrm{~b}$ & $15.31 \mathrm{~b}$ & $18.89 \mathrm{~b}$ & $1.98 \mathrm{a}$ & $2.19 \mathrm{~b}$ & $9.63 \mathrm{~b}$ & $13.12 \mathrm{~b}$ & $2.92 \mathrm{~b}$ & $2.99 \mathrm{~b}$ & $14.18 \mathrm{~b}$ & $17.89 \mathrm{~b}$ \\
\hline Full seasons & $3.47 \mathrm{a}$ & $3.88 \mathrm{a}$ & $22.66 \mathrm{a}$ & $26.19 \mathrm{a}$ & $2.11 \mathrm{a}$ & $2.42 \mathrm{a}$ & $12.29 \mathrm{a}$ & $16.31 \mathrm{a}$ & $3.15 \mathrm{a}$ & $3.26 \mathrm{a}$ & $18.36 \mathrm{a}$ & $21.98 \mathrm{a}$ \\
\hline LSD (0.05) & 0.272 & 0.217 & 2.397 & 1.895 & 0.138 & 0.166 & 1.119 & 1.477 & 0.134 & 0.085 & 1.824 & 1.516 \\
\hline \multicolumn{13}{|c|}{ Trend somparis in of different wee -crop co ipetition seriods ( 3 to 7 wee is) } \\
\hline Linear & $* *$ & $* *$ & $* *$ & $* *$ & $* *$ & $* *$ & $* *$ & $* *$ & $* *$ & $* *$ & $* *$ & $* *$ \\
\hline Quadratic & NS & NS & $* *$ & $* *$ & NS & NS & NS & $* *$ & $\mathrm{NS}$ & NS & $* *$ & $* *$ \\
\hline Cubic & NS & NS & NS & NS & NS & NS & NS & NS & NS & NS & NS & NS \\
\hline
\end{tabular}

WAP: Weeks after Planting. Means followed by the same letter in a column did not differ significantly according to LSD test (P < 0.05 ). NS, * and $* *$ indicate non-significant, significant at $\mathrm{P} \leq 0.05$ level of probability, respectively.

Planta Daninha, Viçosa-MG, v. 33, n. 2, p. 175-182, 2015 cropping season. These results are supported by the research findings of Anjum et al. (2007) and Ikram et al. (2012) who reported that $\mathrm{N}$ uptake by weeds have increased in weedy check. More $\mathrm{P}$ uptake by $R$. capitata during 2012 than during 2011 was due to better climatic conditions during 2012 as more rainfall was received during 2012 (Table 1 ). The same could have happened for $K$ as its uptake also increased with the increase in weed-crop competition periods. These results are also in accordance with the research findings of Anjum et al. (2007) who reported that $\mathrm{K}$ uptake by $T$. portulacastrum was the highest in the treatment where weeds were allowed to grow throughout the cropping season. The faster growth of weeds compared to crops causes quick depletion of nutrients from soil. Weeds removed $72.19 \mathrm{~kg}^{\mathrm{ha}} \mathrm{h}^{-1}$ of $\mathrm{K}_{2} \mathrm{O}$ in weedy plots (Gaikwad \& Pawar, 2003).

Micronutrient contents of $R$. capitata were also significantly affected by different crop competition periods (Tables 2 and 3). The highest $\mathrm{Fe}, \mathrm{Mn}, \mathrm{Na}, \mathrm{Zn}, \mathrm{Ca}, \mathrm{Cu}$ and $\mathrm{Mg}$ contents and their subsequent uptake was observed in the plots where $R$. capitata plants were allowed to compete with mungbean 


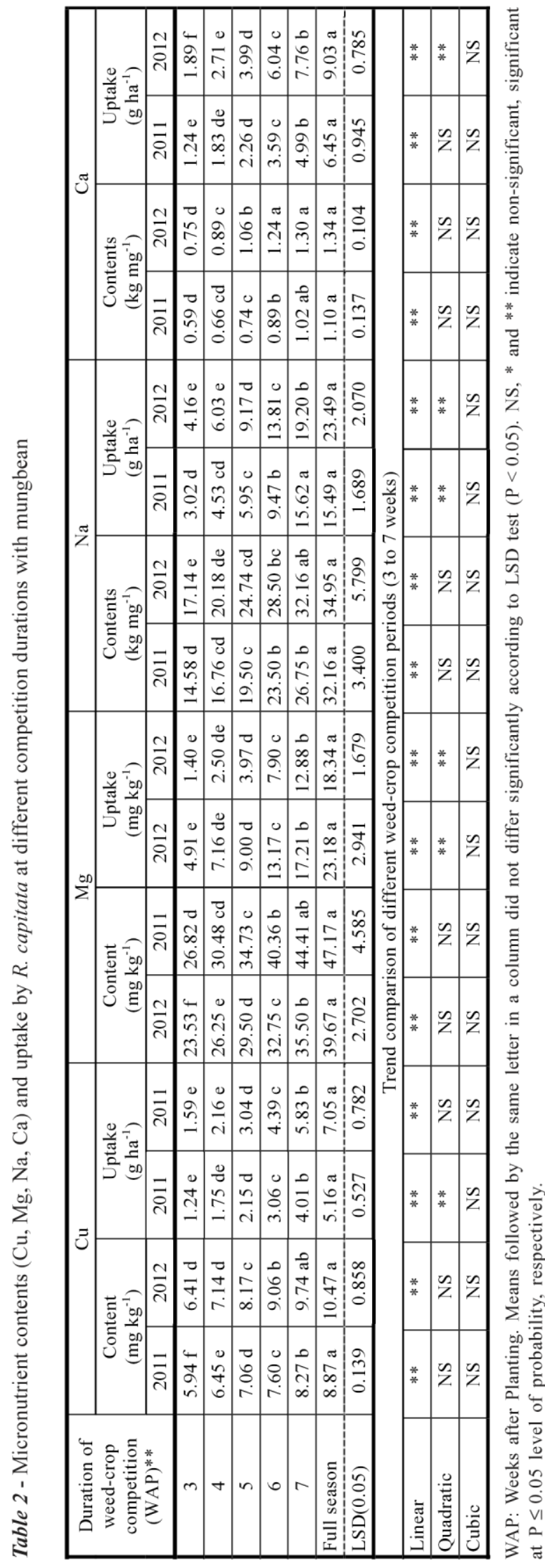

throughout the crop growing season. In trend comparisons of different weed-crop competition periods, only the linear trend was significant with respect to $R$. capitata micronutrient content. However, regarding micronutrient uptake by $R$. capitata, both the linear and quadratic trends were significant. As with the extension in competition period, the uptake of micronutrient by $R$. capitata also increased.

Hence the mungbean plants had fewer micronutrients available for their better growth and development with the increase in $R$. capitata competition duration. These results are similar to the findings of Khattak et al. (2006), who found that $\mathrm{Fe}, \mathrm{Mn}, \mathrm{Zn}, \mathrm{Ca}, \mathrm{Cu}$ and $\mathrm{Mg}$ contents of Amarnath

(Amaranthus retroflexus) were 28.7, 3.8, 4.3, $721.2,1.1$ and 654.8 per $100 \mathrm{~g}$ dry weights, respectively. The contents of these minerals in wild onion (Allium stellatum) were 0.46 , 0.56, $2.98,45.5,2.98$ and $154.7 \mathrm{mg}$ per $100 \mathrm{~g}$ dry weight, respectively.

Number of pods per plant, number of seeds per pod and 1000-seed weight of mungbean were significantly affected by different $R$. capitata competition periods during both years of study (Table 4). The highest number of pods per plant, number of seeds per pod and 1000-seed weight of mungbean wer observed in weed-free plots during both years. Trend comparison of different weed-crop competition periods with respect to these yield components showed that a linear trend was significant. Increased yield indices like number of pods, number of seeds per pods and 1000-seed weight in weed free and short duration competition were due to more availability of light, water etc. and nutrient reserves for mungbean under these conditions, while $R$. capitata plants competing with mungbean for 6-7 weeks or entire season obtained the highest opportunity to make use of nutrient reserves available to the crop, eventually resulted in lower yield indices of mungbean. These results are supported by the findings of Naeem et al. (2000), who reported that the number of pods per plant of mungbean was severely affected by the prolonged competition of weeds and Pascua (1988) also reported that increasing the weed competition period causes a remarkable decrease in the number of pods in mungbean. 
Table 3 - Micronutrient contents (Fe, Mn, Zn) and uptake by R. capitata at different competition durations with mungbean

\begin{tabular}{|c|c|c|c|c|c|c|c|c|c|c|c|c|}
\hline \multirow{3}{*}{$\begin{array}{c}\text { Duration of } \\
\text { weed-crop } \\
\text { competition } \\
\text { (WAP)** }\end{array}$} & \multicolumn{4}{|c|}{$\mathrm{Fe}$} & \multicolumn{4}{|c|}{$\mathrm{Mn}$} & \multicolumn{4}{|c|}{$\mathrm{Zn}$} \\
\hline & \multicolumn{2}{|c|}{ Content (\%) } & \multicolumn{2}{|c|}{ Uptake $\left(\mathrm{kg} \mathrm{ha}^{-1}\right)$} & \multicolumn{2}{|c|}{ Content (\%) } & \multicolumn{2}{|c|}{ Uptake $\left(\mathrm{kg} \mathrm{ha}^{-1}\right)$} & \multicolumn{2}{|c|}{ Content (\%) } & \multicolumn{2}{|c|}{ Uptake $\left(\mathrm{kg} \mathrm{ha}^{-1}\right)$} \\
\hline & 2011 & 2012 & 2011 & 2012 & 2011 & 2012 & 2011 & 2012 & 2011 & 2012 & 2011 & 2012 \\
\hline 3 & $39.97 \mathrm{~d}$ & $47.60 \mathrm{~d}$ & $8.45 \mathrm{e}$ & $11.84 \mathrm{e}$ & $31.02 \mathrm{f}$ & $38.77 \mathrm{e}$ & $6.59 \mathrm{e}$ & $9.45 \mathrm{f}$ & $16.90 \mathrm{~d}$ & $20.15 \mathrm{e}$ & $3.02 \mathrm{~d}$ & $4.16 \mathrm{e}$ \\
\hline 4 & $47.59 \mathrm{~d}$ & $58.97 \mathrm{~cd}$ & $12.89 \mathrm{de}$ & $17.52 \mathrm{e}$ & $35.42 \mathrm{e}$ & $48.06 \mathrm{~d}$ & $9.61 \mathrm{de}$ & $14.43 \mathrm{e}$ & $18.50 \mathrm{~d}$ & $24.30 \mathrm{~d}$ & $4.53 \mathrm{~cd}$ & $6.03 \mathrm{e}$ \\
\hline 5 & $61.25 \mathrm{c}$ & $72.45 \mathrm{c}$ & $18.68 \mathrm{~d}$ & $27.08 \mathrm{~d}$ & $40.25 \mathrm{~d}$ & $60.49 \mathrm{c}$ & $12.20 \mathrm{~d}$ & $22.47 \mathrm{~d}$ & $21.25 \mathrm{c}$ & $28.93 \mathrm{c}$ & $5.95 \mathrm{c}$ & $9.17 \mathrm{~d}$ \\
\hline 6 & $75.06 \mathrm{~b}$ & $87.74 \mathrm{~b}$ & $30.22 \mathrm{c}$ & $42.56 \mathrm{c}$ & $47.80 \mathrm{c}$ & $72.63 \mathrm{~b}$ & $19.23 \mathrm{c}$ & $35.19 \mathrm{c}$ & $23.50 \mathrm{bc}$ & $33.72 \mathrm{~b}$ & $9.47 \mathrm{~b}$ & $13.81 \mathrm{c}$ \\
\hline 7 & $90.99 \mathrm{a}$ & $100.29 \mathrm{ab}$ & $44.06 \mathrm{~b}$ & $59.86 \mathrm{~b}$ & $57.05 \mathrm{~b}$ & $79.75 \mathrm{ab}$ & $27.66 \mathrm{~b}$ & $47.67 \mathrm{~b}$ & $25.75 \mathrm{~b}$ & $35.53 \mathrm{~b}$ & $15.62 \mathrm{a}$ & $19.20 \mathrm{~b}$ \\
\hline Full season & $97.50 \mathrm{a}$ & $112.25 \mathrm{a}$ & $57.09 \mathrm{a}$ & $75.47 \mathrm{a}$ & $63.50 \mathrm{a}$ & $83.14 \mathrm{a}$ & $36.92 \mathrm{a}$ & $55.91 \mathrm{a}$ & $29.75 \mathrm{a}$ & $40.51 \mathrm{a}$ & $15.49 \mathrm{a}$ & $23.49 \mathrm{a}$ \\
\hline $\operatorname{LSD}(0.05)$ & 8.864 & 14.77 & 8.925 & 6.542 & 3.707 & 7.725 & 3.232 & 3.293 & 2.602 & 3.310 & 1.689 & 2.070 \\
\hline \multicolumn{13}{|c|}{ Trend comparison of different weed-crop competition periods ( 3 to 7 weeks) } \\
\hline Linear & $* *$ & $* *$ & $* *$ & $* *$ & $* *$ & $* *$ & $* *$ & $* *$ & $* *$ & $* *$ & $* *$ & $* *$ \\
\hline Quadratic & NS & NS & $* *$ & $* *$ & NS & NS & $* *$ & ** & NS & NS & ** & $* *$ \\
\hline Cubic & NS & NS & NS & NS & NS & NS & NS & NS & NS & NS & NS & NS \\
\hline
\end{tabular}

WAP: Weeks after Planting. Means followed by the same letter in a column did not differ significantly according to LSD test $(\mathrm{P}<0.05)$. NS, * and ** indicate non-significant, significant at $\mathrm{P} \leq 0.05$ level of probability, respectively.

Table 4 - Effect of the weed competition periods on yield and yield parameters of mungbean

\begin{tabular}{|c|c|c|c|c|c|c|c|c|}
\hline \multirow{2}{*}{$\begin{array}{l}\text { Weed-crop } \\
\text { competition } \\
(\text { WAP })\end{array}$} & \multicolumn{2}{|c|}{$\begin{array}{c}\text { Number of pods per } \\
\text { plant }\end{array}$} & \multicolumn{2}{|c|}{ Number of seeds per pod } & \multicolumn{2}{|c|}{ 1000-seed weight (g) } & \multicolumn{2}{|c|}{ Seed yield $\left(\mathrm{kg} \mathrm{ha}^{-1}\right)$} \\
\hline & 2011 & 2011 & 2011 & 2011 & 2011 & 2012 & 2011 & 2012 \\
\hline 0 & $38.50 \mathrm{a}$ & $29.50 \mathrm{a}$ & $10.50 \mathrm{a}$ & $9.75 \mathrm{a}$ & $54.00 \mathrm{a}$ & $47.25 \mathrm{a}$ & $1688.6 \mathrm{a}$ & $1495.5 \mathrm{a}$ \\
\hline 3 & $36.00 \mathrm{~b}$ & $25.25 \mathrm{~b}$ & $10.25 \mathrm{ab}$ & $9.25 \mathrm{ab}$ & $50.50 \mathrm{~b}$ & $46.00 \mathrm{ab}$ & $1582.0 \mathrm{~b}$ & $1404.0 \mathrm{~b}$ \\
\hline 4 & $34.25 \mathrm{~b}$ & $23.00 \mathrm{~b}$ & $9.75 \mathrm{ab}$ & $8.75 \mathrm{bc}$ & $48.25 \mathrm{~b}$ & $43.75 \mathrm{~b}$ & $1477.8 \mathrm{c}$ & $1300.3 \mathrm{c}$ \\
\hline 5 & $31.50 \mathrm{c}$ & $20.25 \mathrm{c}$ & $9.50 \mathrm{bc}$ & $8.12 \mathrm{c}$ & $44.00 \mathrm{c}$ & $40.50 \mathrm{c}$ & $1308.3 \mathrm{~d}$ & $1187.3 \mathrm{~d}$ \\
\hline 6 & $29.50 \mathrm{c}$ & $18.50 \mathrm{~cd}$ & $8.75 \mathrm{~cd}$ & $8.00 \mathrm{c}$ & $40.75 \mathrm{~d}$ & $37.75 \mathrm{~d}$ & $1155.6 \mathrm{e}$ & $1036.3 \mathrm{e}$ \\
\hline 7 & $27.25 \mathrm{~d}$ & $17.00 \mathrm{~d}$ & $8.25 \mathrm{~d}$ & $8.00 \mathrm{c}$ & $37.00 \mathrm{e}$ & $35.50 \mathrm{~d}$ & $975.8 \mathrm{f}$ & $878.8 \mathrm{f}$ \\
\hline Full season & $23.25 \mathrm{e}$ & $14.00 \mathrm{e}$ & $8.000 \mathrm{~d}$ & $8.12 \mathrm{c}$ & $34.75 \mathrm{e}$ & $30.50 \mathrm{e}$ & $869.3 \mathrm{~g}$ & $803.8 \mathrm{~g}$ \\
\hline LSD & 2.2225 & 2.395 & 0.999 & 0.830 & 2.977 & 2.538 & 46.899 & 52.739 \\
\hline \multicolumn{9}{|c|}{ Trend comparison of different weed-crop competition periods ( 3 to 7 weeks) } \\
\hline Linear & ** & *** & *** & $* *$ & *** & *** & $* *$ & *** \\
\hline Quadratic & NS & NS & NS & NS & NS & NS & NS & NS \\
\hline Cubic & NS & NS & NS & NS & NS & NS & NS & NS \\
\hline
\end{tabular}

WAP: Weeks after Planting. Means followed by the same letter in a column did not differ significantly according to LSD test $(\mathrm{P}<0.05)$. NS, * and ** indicate non-significant, significant at $\mathrm{P} \leq 0.05$ level of probability, respectively.

Weed competition duration had a significant effect on mungbean seed yield per hectare during both years. Increasing $R$. capitata competition period considerably decreased the seed yield of mungbean (Table 4). Moreover, mungbean seed yield response to increasing $R$. capitata competition duration was linear during both experimental years.
During both years, the highest seed yield was recorded in weed-free plots and the declining yield was observed as the competition period was prolonged. In the weedy check (competition for full season), 49 and 46\% yield losses were observed for 2011 and 2012, respectively, and minimum yield losses $(6 \%)$ were observed in the 3 week competition 
period (Figure 5). Correlation analysis has showed that seed yield of mungbean had a strong negative association with the

$R$. capitata competition period (Figure 3 ) and $R$. capitata dry weight (Figure 4) during both

adverse effect on the yield potential of mungbean. These results are in great agreement with those of Naeem et al. (2000),

years of study.

Competition period (weeks)

Figure 3 - Regression analysis of effect of the competition period on seed yield of mungbean.
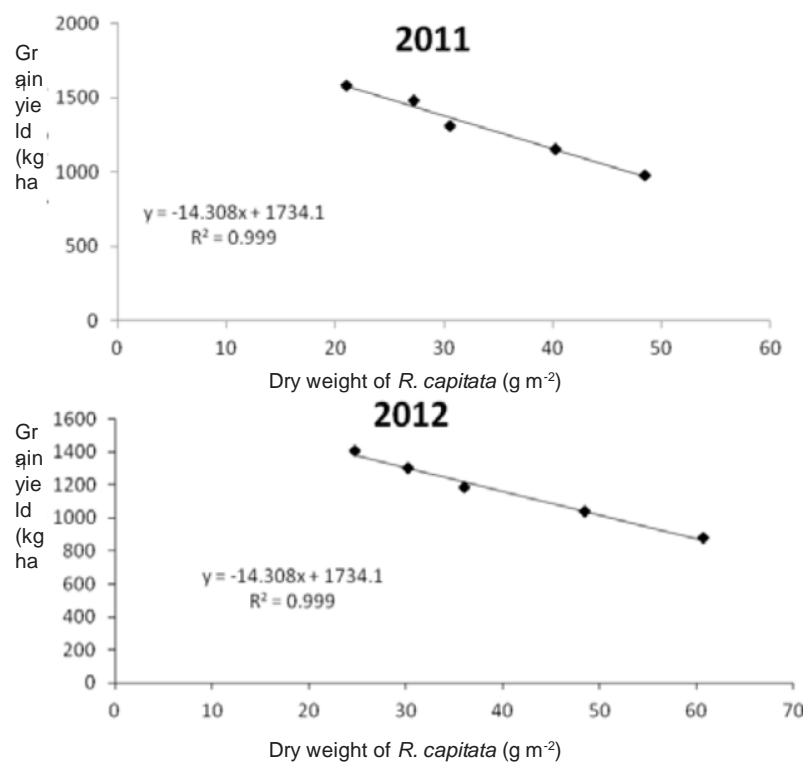

Figure 4 - Correlation between the dry weight of $R$. capitata and seed yield of mungbean.

The decrease in seed yield with increase in the competition period was due to a decrease in the major yield components like number of pods per plant, number of seeds per pod and 1000-seed weight. The results

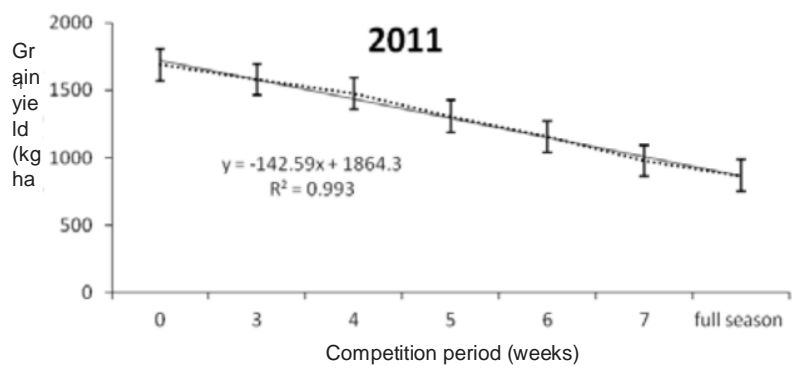

2012

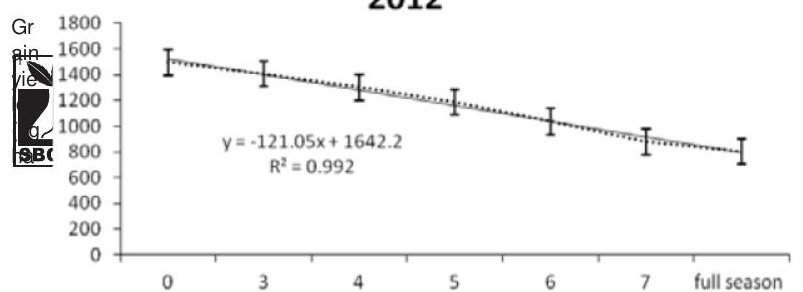

further led to the conclusion that $R$. capitata competition with crop up to 3 weeks after planting of mungbean crop had little effect on growth and development of mungbean, while extended $R$. capitata competition duration had an who found that weed competition duration had a significant effect on final seed yield per hectare in mungbean. Utomo (1989) also reported that the mungbean crop was very sensitive to competition from weeds during 3 to 6 weeks after planting. Malik et al. (2000) also reported that weed competition with mungbean decreased seed yield by $81 \%$ and according to Raman \& Krishnamoorthy (2005) weed-crop competition for the whole mungbean crop season decreased the mungbean seed yield by $35 \%$. It was also observed in these experiments that the $R$. capitata completes its growth stages with the mungbean crop and a great quantity of $R$. capitata seed was dispersed into the soil before the crop was harvested. If $R$. capitata will be eliminated or disturbed earlier than its seed set, the mungbean yield losses will be lessened in the long run. Rhynchosia capitata can significantly decrease the seed yield of mungbean up to $49 \%$ if left uncontrolled for the whole crop season; therefore its early management is crucial.

\section{LITERATURE CITED}

ALI, H. H. et al. Methods to break seed dormancy of Rhynchosia capitata, a summer annual weed. Chilean J. Agri. Res., v. 71, n. 3, p. 483-487, 2011.

ALI, H. H.; TANVEER, A.; NADEEM, M. A. Evaluation of some seed dormancy breaking methods on germination of Rhynchosia capitata (Roth DC). Pak J. Weed Sci Res., v. 18, n. 4, p. 423-432, 2012.

ALI, H. H. et al. Germination ecology of Rhynchosia capitata: an emerging summer weed in Asia. Planta

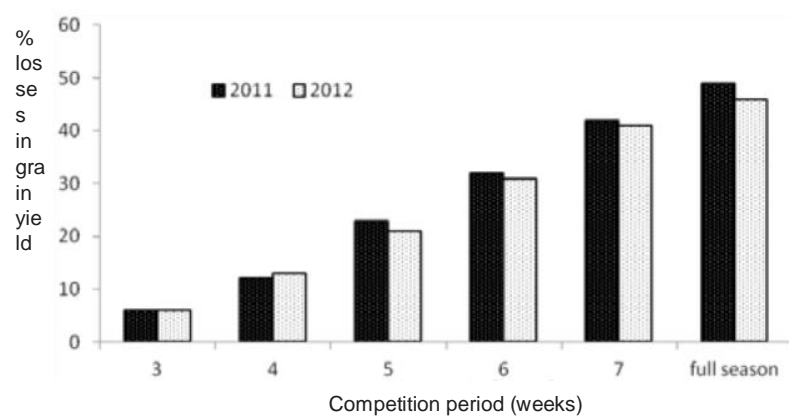

Figure 5 - Yield losses (\%) in mungbean with increasing R. capitata competition periods.

Planta Daninha, Viçosa-MG, v. 33, n. 2, p. 175-182, 2015 
Daninha, v. 31, n. 2, p. 249-257, 2013a.

ALI, H. H. et al. Allelopathic effects of Rhynchosia capitata on germination and seedling growth of mungbean.

Planta Daninha, v. 31, n. 3, p. 501-509, 2013b.

ANJUM, F. H. et al. Effect of split application of nitrogen and integrated weed management on nutrient uptake by Trianthema portulacastrum (itsit) in cotton. Pak. J. Agri Sci., v. 44, n. 3, p. 423-429, 2007.

\section{ASSOCIATION OF OFFICIAL ANALYTICAL}

CHEMISTS - AOAC. Official methods of analysis of the AOAC. 14.ed. Washington: 1984.

ARSHAD, M. et al. AZRI mung-2006: A high yielding short duration and bold seeded mungbean variety. J. Agri. Res., v. 46, n. 2, p. 299-307, 2006.

DEEN, W.; COUSENS, R.; WARRINGA, J. An evaluation of four crop: Weed competition models using a common data set. Weed Res., v. 43, n. 2, p. 116-129, 2003.

DOGRA, K. S. et al. Comparison of understorey vegetation in exotic and indigenous tree plantations in Shivalik Hills of N.W. Indian Himalayas (Himachal Pradesh). J Ecol. Nat. Environ., v. 1, n. 5, p. 130-136, 2009.

GAIKWAD, R. P.; PAWAR, V.S. Effect of Herbicides on Soybean crop and weeds. Ind. J. Weed Sci., v. 35, n. 1, p. 145-147, 2003.

IKRAM, R. M. et al. Comparative efficacy of different preemergence herbicides in controlling weeds in cotton (Gossypium hirsutum L.). Pak J. Weed Sci. Res., v. 18, n. 1, p. 209-222, 2012.

ILDIS: online. International Legume Database and Information Service. [cited 2010 January11]. <Available from: http://www.ildis.org/LegumeWeb, 2010>.

JAN, G. et al. Nutritional analysis, micronutrients and chlorophyll contents of Cichorium intybus L. J. Med Plants Res., v. 5, n. 12, p. 2452-2456, 2011.

KHATTAK, I. A.; KHAN, I. A.; NAZIF, W. Weeds as human food- a conquest for cheaper mineral sources. J. Agric. Biol. Sci., v. 1, n. 2, p. 12-15, 2006.

MALIK, R. S.; YADAV, A.; MALIK, R. K. Efficacy of trifluralin, linuron and acetachlor against weeds in mungbean (Vigna radiata). Indian J. Weed Sci., v. 32, n. 3-4, p. 181-185, 2000.

MANSOOR, M. et al. Development of Economical Weed Management Strategies for Mungbean (Vigna radiate L.

Planta Daninha, Viçosa-MG, v. 33, n. 2, p. 175-182, 2015
Wilczek.).Pak. J. Weed Sci. Res., v. 10, n. 3-4, p. 151156, 2004.

MCDONALD, A. J.; RIHA, S. J.; MOHLER, C. L. Mining the record: historical evidence for climatic influences on maize-Abutilon theophrasti competition. Weed Res., v. 44, n. 6, p. 439-445, 2004.

MOODY, K. Weed control in mungbean. In: INTERNATIONAL SYMPOSIUM ON MUNGBEAN, 1., 1977, Los Banos. Proceedings... Los Banos: 1978. p. $132-136$,

NAEEM, M.; AHMED, S.; CHEEMA, Z. A. Yield of mungbean as affected by different durations of weed competition under high phosphorus status. Inter. J. Agric. Biol., v. 2, n.1-2, p. 133-135, 2000.

NORSWORTHY, J. K.; OLIVEIRA, M. J. Coffee senna (Cassia occiden-talis) germination and emergence is influenced by environmental factors and seeding depth. Weed Sci., v. 53, n. 5, p. 657-662, 2005.

PANDEY, J.; MISHRA, B. N. Effect of weed management practices in a rice-mustard-mungbean cropping system on weeds and yield of crops. Ann. Agric. Res., v. 24, n. 1, p. 737-742, 2003.

ASCUA, A. C. Duration of weed control and weed competition of mungbean yield. Philippines J. Crop Sci., v. 13 , n. 1 , p. $230-235,1988$.

RAMAN, R.; KRISHNAMOORTHY, R. Nodulation and yield of mungbean (Vigna radiate L.) influenced by integrated weed management practices. Legume Res., v. 28, n. 2, p. 128-130, 2005.

SHARMA, N. K.; SHARMA, M. M.; SEN, D. N. Seed perpetuation in Rhynchosia capitata DC. Biol. Plant., v. 20, n. 1, p. 225-228, 1978.

STEEL, R. G. D.; TORRIE, J. H.; DICKEY, D. A. Principles and procedures of statistics. A biometrical approach. 3.ed. Singapore: McGraw Hill Book, 1997. p. 172-177.

UTOMO, I. H. Critical period of mungbean (Phaseolus Radiates L.) to weed competition. Biotropia, v. 2, n. 2 , p. 8-11, 1989. 